Nig J. Biotech. Vol. 31 (2016) $66-73$

ISSN: 01891731

Available online at

http://www.ajol.info/index.php/njb/index

and www.biotechsocietynigeria.org

DOI: http://dx.doi.org/10.4314/njb.v31i1.9

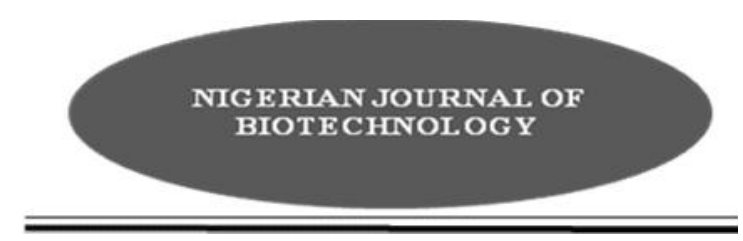

\title{
Possible Changes in Heavy metals Bioaccumulation in Fish Liver in selected Rivers of Ebonyi state
}

\author{
Nwabunike, M .O. \\ Department of Fisheries and Aquaculture, Department of Fisheries and Aquaculture, \\ Ebonyi State University, Abakaliki, Nigeria
}

(Received: 07:03:2016; Accepted: 29:07:2016)

\begin{abstract}
This study examined possible changes in fish liver caused by heavy metals bioaccumulation in selected rivers of Ebonyi State. The livers of sampled fishes were dissected and cleaned with $\mathrm{HNO}_{3}$ and washed with de-ionized water, dried at $105^{\circ} \mathrm{C}$ for about 12 hours. Samples for metal bioaccumulation were taken from each fish and delivered for analyses at 11TA laboratory. Data collected were subjected to line graphs analysis. The result showed a considerable fluctuation of cadmium in varying magnitudes. Chromium bioaccumulation varied in fish liver from month to month and increased as age of fish increased. Mkpuma fish liver showed highest lead bioaccumulation from 10.5 - 24.5ppm followed by Ameka Dam 10.8 - 9.6ppm with the two controls lying between the ranges of 5.0 - 9.6ppm. Arsenic accumulation in the liver of fishes harvested from the five locations showed bioaccumulation from April to December before encroachment. This dropped as encroachment took place between January - March 2011 and took the same trend in 2012 with the exception of Mkpuma fish liver that did not witness any encroachment. Among the recommendations of the researcher was that; there should be periodic monitoring of the rivers to avoid waste disposal which could lead to heavy metals bioaccumulation.
\end{abstract}

keywords: heavy, metals, bioaccumulation, fish, river, liver

Correspondence: Evanmaur@gmail.com, Ojobaokanya@gmail.com

\section{Introduction}

Fish is an important food source for the human body, providing essential fatty acids like omega 3, proteins, vitamins and minerals. Despite its nutritive value consumption of fish brings many times a potential hazard concern for the human consumers. Heavy metals enter the aquatic environment mainly by anthropogenic sources (Nwabunike, 2016). Fish is at the top of the aquatic food chain, and during its life can accumulate large amounts of toxic elements, including heavy metals. Heavy metals are defined by their weight and to be classified as a heavy metal, it must have a specific gravity of 2.7 . One category of toxic contaminants accumulated by fishes in their various organs and muscles are heavy metals such as lead $(\mathrm{Pb})$, mercury $(\mathrm{Hg})$, cadmium $(\mathrm{Cd})$ chromium ( $\mathrm{Cr}$ ) and arsenic (As) (Domingo et al, 2007). Any of these heavy metals can destroy life when they concentrate in the body above acceptable levels. Thus, eating contaminated fish predisposes the consumer to health hazards.

Currently, Ebonyi State is endowed with abundant agricultural and mineral resources, huge potentials for tourisms development as well as many rivers and rivulets. Several mineral deposits abound at economic levels including untarnished natural salt lakes, huge deposits of granites, limestone or dolomite, sand and gypsum. Others are bauxite, zinc, lead, quartz, copper, gold, uranium and even crude oil. Farming activities by the people of the state eventually introduce most of these chemicals into nearby water bodies and lead to water pollution. Release of toxic chemicals into the water is obviously harmful to aquatic flora and fauna. Even surface runoffs of soil and rock debris although non-toxic can also be harmful to aquatic lives in water bodies in such areas.

Besides pollution, mining processes use water from nearby water sources. Sometimes, abandoned quarry pits turn into stagnant lakes 
which also create breeding ground for mosquitoes and black flies, further spreading diseases within the locality. These waters have been reported to contain toxic and hazardous substances including heavy metals, which eventually settle in bottom sediments (Overcash et al., 1978; Ademoroti, 1996; Oguzie, 2002). Biney et al. (1994) stated that microbial and redox processes may change the properties of sediments and affect the composition of interstitial water, while reworking of the sediments by organisms will also bring sediments to the surface, where a significant fraction of heavy metals will be released. A good knowledge of the distribution of heavy metals in water and sediments plays a key role in detecting the sources of pollution in aquatic systems (Forstner and Wittmann, 1981; IdodoUmeh and Oronsaye, 2006).

There are numerous heavy metals, some of which are highly toxic, like mercury, lead, arsenic, and cadmium. Fish accumulate toxic materials at various levels, depending on species, age, season, feeding habits (Tkacheva, 2000), and so on. None of the metals are biodegradable, and though they can change forms from solid, to liquid, to dust and gas, they never completely disappear. The ones that are toxic in even the same minute amounts create instant cellular destruction in any of their forms (Oguzie, 2002). Aquatic animals such as fish are able to readily absorb metals and their bodies regulate to accommodate their presence. They are easily stored in fatty tissue and will bioaccumulate if the fish is exposed to further contamination (Sindayigaya et al., 1994). Thus, this study investigated the changes in bioaccumulation of heavy metals in fish liver in the selected rivers of Ebonyi state.

\section{Materials and methods}

Study Area: The study area is Ebonyi State of Nigeria. The State is located in the Eastern part of Nigeria and lies approximately $7^{\circ} 3^{\prime} \mathrm{N}$ and longitudes $5^{\circ} 4^{\prime} \mathrm{E}$ and $6^{\circ} 45^{\prime} \mathrm{W}$. The state is made up of thirteen (13) local government areas, which are divided into three (3) agricultural zones, namely: Ebonyi North, Ebonyi Central and Ebonyi South. It has a landmass of approximately 5,932 square kilometers. It is bounded in the East by Cross River State, in the North by Benue State, in the West by Enugu
State, and in the South by Abia State (EBMOI, 2005). Ebonyi State has a population of 2.1 million people (NPC, 2006). The vegetation of the state is a mixture of savanna and semi-tropical forest with agriculture and mining as the mainstay of the economy. It lies in an area of moderate relief of between 125 metres and 245 metres above sea level. The soil is texturally clay loam, fairly to poorly drained, with gravely subsoil in some locations especially the upland adjacent to lowland areas (Ekpe et al., 2005). Crops grown in the area include; rice, yam, cassava, cocoyam, groundnut, cowpea and vegetables. Livestock farming, especially the extensive system of rearing sheep, goats and native cattle, is also practiced by the people. Fishing activities are predominant in all the zones of the state. Ekpe et al (2005) noted that three main seasons prevail in the area - the rainy (wet) season, which spans from early April to early November, the harmattan period which lasts between mid-November to late January and the dry season, which lasts from late January to early April. However, a short dry spell is usually experienced during the month of August, and this is termed the August break. Lowland areas popularly called, FADAMA are largely available and serve as good sites for rice and fish farming during the rain and dry season vegetable farming. Some non-farm activities prevalent in the State include: quarrying, petty trading, pottery, weaving etc. Medium to large-scale industries also exist in the state. Notable among them are the Abakaliki rice milling industry, the fertilizer blending plant and the building materials industry. Large deposits of solid mineral resources such as lead, gold, gellena, zinc, iron, oxide, quartz, greeze, gypsum, limestone, marble stone, common salt and others are found in Ebonyi State (EBMO1, 2005).

Field Sampling: Three locations within the river systems in Ebonyi State, lying close to mine sites were sampled (Mkpuma river, Akpara dam and Enyigba river) on monthly bases for two years beginning from March 2011 to February 2013. Then a river system which does not lie close to any mining site was used to serve as control 1. Culture pond water using urban tap water to culture Clarias albopunctatus was used as control 2. Specimen of Clarias 
albopunctatus were collected from the Ebonyi state university earthen pond and acclimatized to the laboratory conditions for fifteen days. The fishes were fed with coupens industrial feed at $3 \%$ body weight twice daily. The fishes, measuring 4 to $6 \mathrm{~cm}$ in length and weighing 8 to $10 \mathrm{gm}$ were selected for the experimental purpose. The physiochemical parameters of the water were estimated according to Apha (1981). The test specimens were stocked in a concrete pond supplied with urban tap water as the water was changed bimonthly. The control fish was sampled monthly, for onward processing and preservation for analytical purpose.

$$
\text { Analysis of Heavy Metals }
$$

Bioaccumulation: After taking fork length measurements and weights of all the fishes caught from each water body, five (5) fishes were purposively selected based on age. The blood samples were collected with a syringe guage of syringe into a centrifuge vial and samples of skeletal muscles (2-3) were dissected from the left side between the dorsal fin and the lateral line of each fish. The whole livers were dissected, dressed and cleaned with $\mathrm{HNO}_{3}$. Each vial was cleaned with $\mathrm{HNO}_{3}$ for 5 hours and washed thoroughly with deionized water, rinsed 3 times, dried (Tkacheva, 2000). Samples were dried at $105^{\circ} \mathrm{C}$ for about 12 hours, ground,

\section{Result}

Considerable fluctuation in bio-accumulation of cadmium in varying magnitudes were observed in livers of harvested fishes (Fig 1). This ranged from March-April 2011, February-March 2012 and December - February 2013 in fish livers harvested from Enyigba River that witnessed the highest effect of poachers. In Ameka Dam, fish packaged, labeled, pre-weighed and packed in plastic boxes with lids. Samples for metal bioaccumulation, enzyme and lipid analyses were taken from each fish simultaneously and placed in separate vials and delivered for analyses at 11TA laboratory. Determination of heavy metals $\mathrm{Cd}, \mathrm{Ni}, \mathrm{Hg}, \mathrm{Cr}, \mathrm{Pb}$, and as was done using Buck 211VGP AAS made by Buck scientific, Inc., East Norwalk. The digest of the ash of each sample above as obtained in calcium and potassium determination was washed into $100 \mathrm{ml}$ volumetric flask with distilled water and made up to mark. This diluent was aspirated into the Buck 211VGP Atomic Absorption Spectrophotometer (AAS) through the suction tube. Each of the trace mineral elements was read at their respective wavelengths with their respective hollow cathode lamps using appropriate fuel and oxidant combination.

Data Analysis: Data collected from the laboratory analyses of fish for the body burden of heavy metals identified from the three sampling locations and controls, were subjected to statistical analysis. Descriptive statistics in form of line graphs were used to represent the bioaccumulation of the heavy metals as the fish grow from age one to two years.

livers had an ascending bioaccumulation as fish aged, but with a little shake off during harmattan seasons with the range of 1.002.5ppm. In Mkpuma river, fish liver had a continuous ascension of bioaccumulation ranging from 1.3-3.9 ppm.

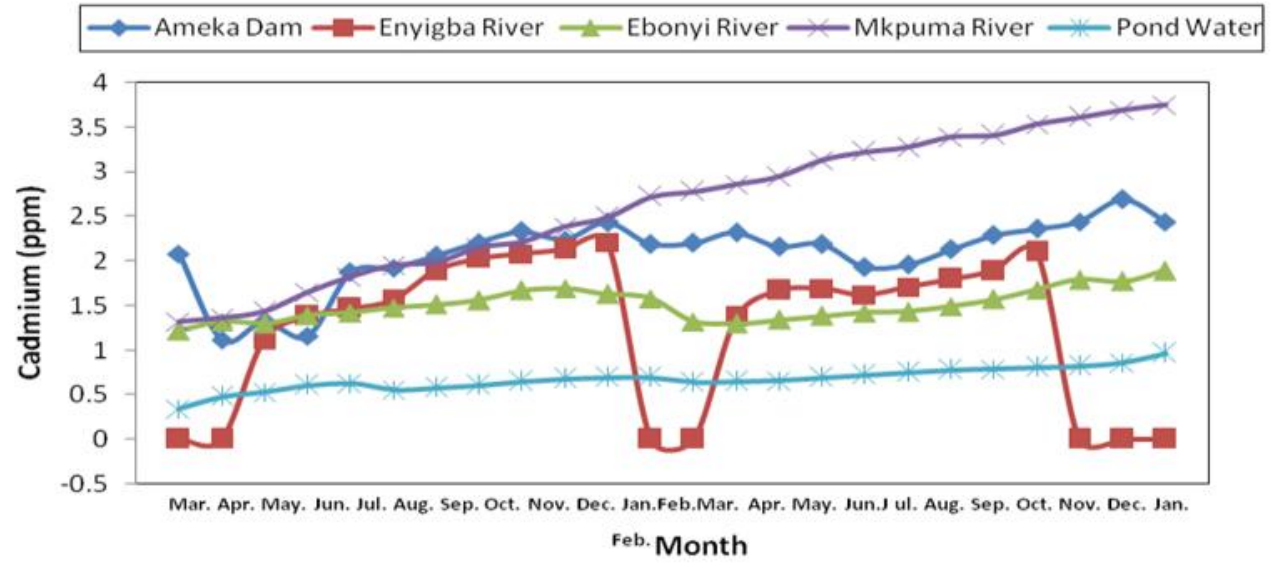

Fig. 1: Variations of Cadmium (Ca) Content in the Liver of Catfish in Five Mining Sites in Ebonyi State from March 2011 to February 2013 
Fish livers in the two controls, Ebonyi River and pond water witnessed cadmium bioaccumulation within the ranges of 0.3 $1.6 \mathrm{ppm}$. Very high accumulation of nickel was observed in fish liver of harvests from mine effluent areas with bioaccumulation ranging from 6.3-9.4 (Fig 2).

The 0.00 points as witnessed in J anuary - March in Enyigba was as a result of small size fishes which had undeveloped livers at the time of harvest. Akpara Dam and Mkpuma River showed an ascending bioaccumulation of nickel for the two years (i.e $6.5 \mathrm{ppm}-9.4 \mathrm{ppm}$ ). Fish livers in the control river ranged from 3.50 $4.20 \mathrm{ppm}$ and showed an ascending bioaccumulation as well.

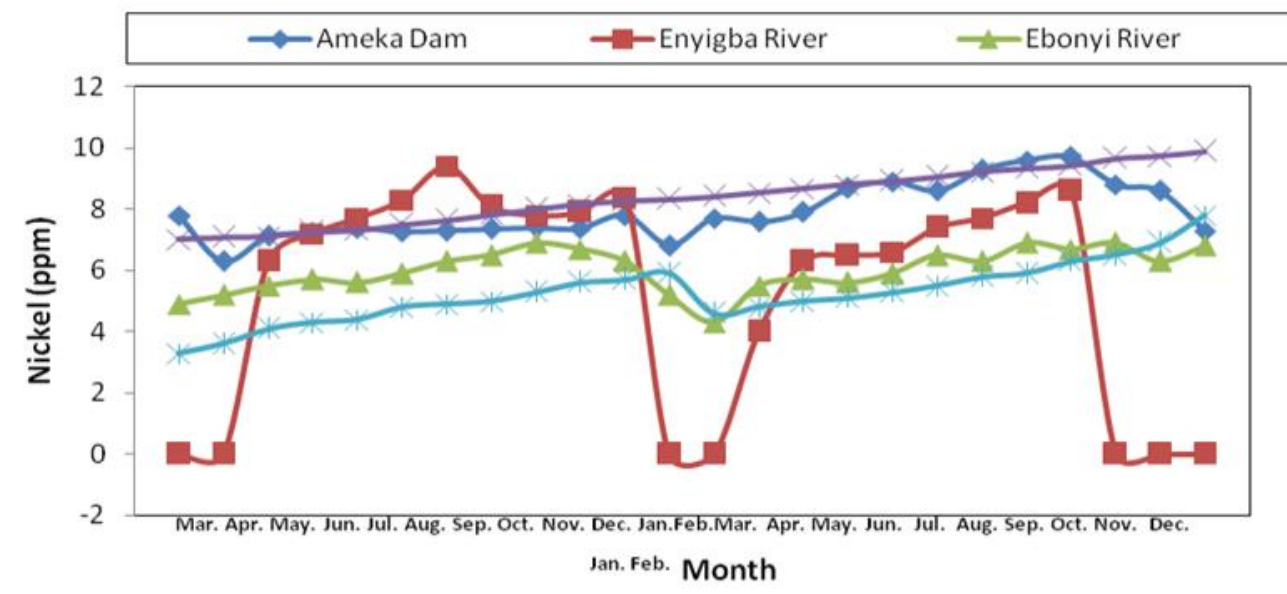

Figure 2: Variations of Nickel (Ni) Content in the Liver of Catfish in Five Mining Sites in Ebonyi State from March 2011 to February 2013

Bio-accumulation of mercury increased as fish age increased (Fig 3). From the slope of the graph on mercury in liver of fish found in Mkpuma river, its bio-accumulation ranged from $0.36-0.96 \mathrm{ppm}$ and $0.42-0.70 \mathrm{ppm}$ in liver of fish found in Enyigba. With fish age running from March - February a drop from January April depicted a drop in fish size due to vandalisation by communal encroachment.

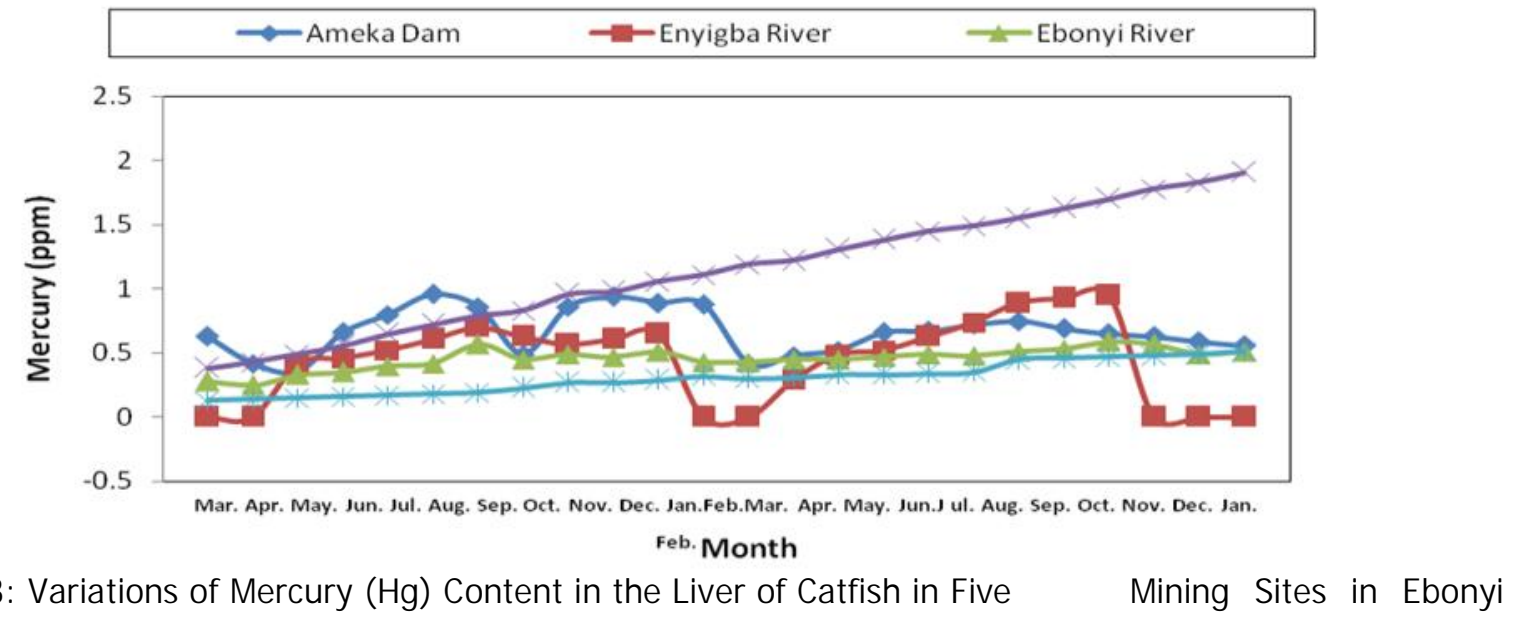

Figure 3: Variations of Mercury $(\mathrm{Hg})$ Content in the Liver of Catfish in Five Mining Sites in Ebonyi State from March 2011 to February 2013

Chromium bioaccumulation varied in fish liver from month to month and increased as age of fish increased (Fig 4). It witnessed an even trend from April - January 2011 and dropped after vandalization between January - March and continued along the trend in the five water bodies fish livers at the range of 13.11 26.17ppm. 


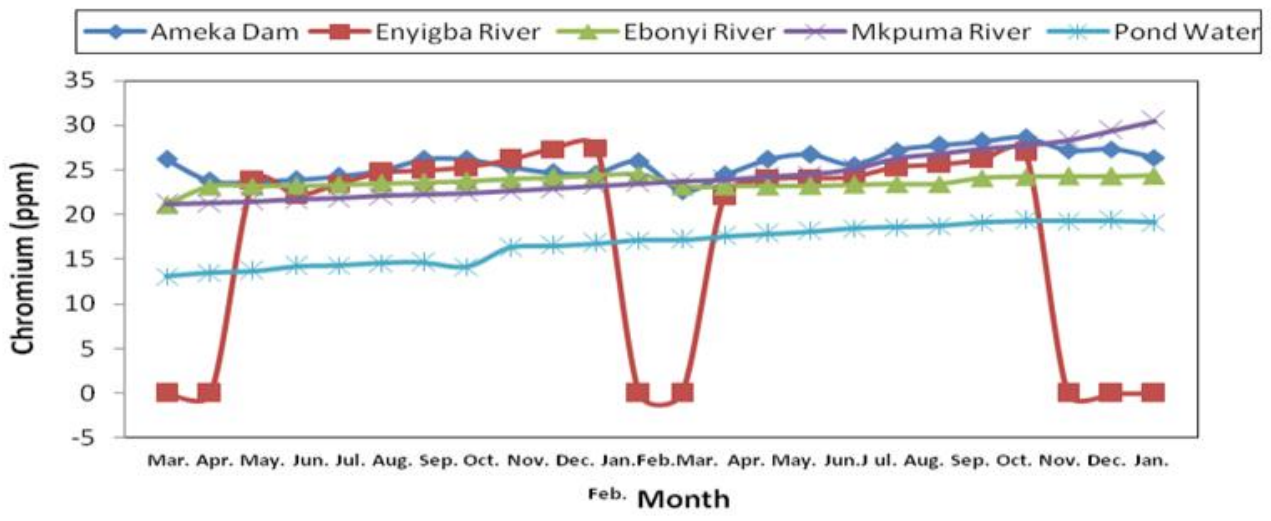

Figure 4: Variations of Chromium ( $\mathrm{Cr}$ ) Content in the Liver of Catfish in Five Mining Sites in Ebonyi State from March 2011 to February 2013

Bioaccumulation of lead ranged from the value of $4.5-5.0 p p m$ (Fig 5). The liver of fish found in Mkpuma showed highest lead bioaccumulation from $10.5-24.5 \mathrm{ppm}$ followed by that in Ameka Akpara Dam 10.8 - 9.6ppm, with the two controls lying between the ranges of $5.0-9.6 \mathrm{ppm}$.

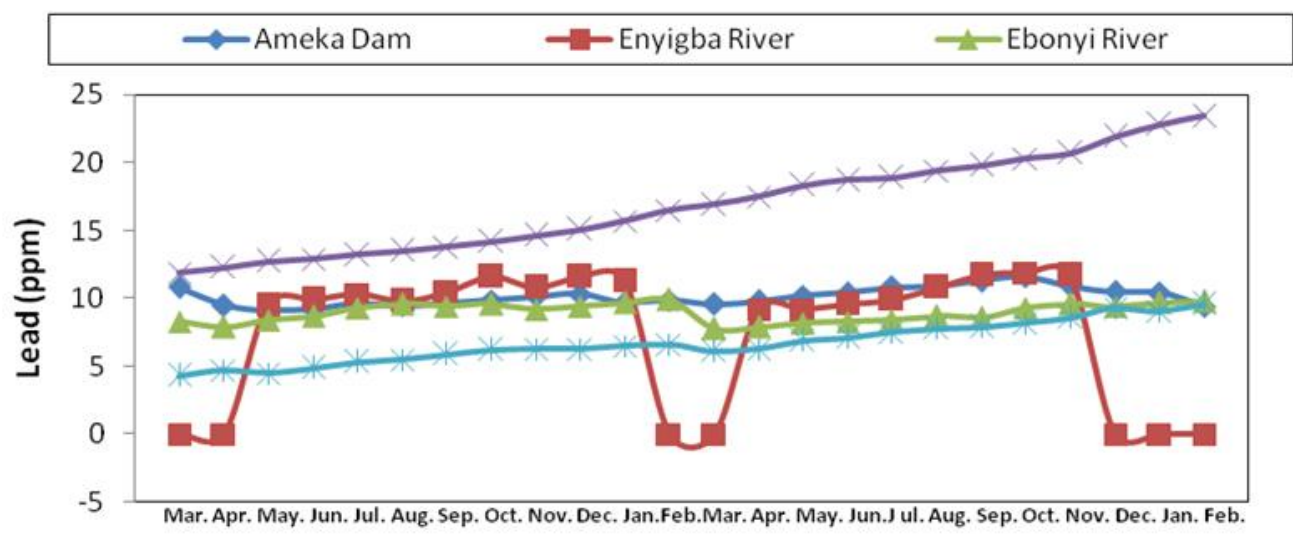

Month

Figure 5: Variations of Lead $(\mathrm{Pb})$ content in the Liver of Catfish in Five Mining Sites in Ebonyi State from March 2011 to February 2013

Arsenic accumulation in the liver of fishes harvested from five locations showed bioaccumulation from April to December before encroachment (Fig 6). This dropped as encroachment took place between January March 2011 and took the same trend in 2012 with the exception of Mkpuma fish liver that did not witness any encroachment.

\section{Discussion}

Considerable fluctuation of cadmium in varying magnitudes was observed in the bioaccumulation in fish livers of harvested fish. This ranged from March-April 2011, February-
March 2012 and December - February 2013 in fish livers harvested from Enyigba River that witnessed the highest effect of poachers. Ameka Dam fish livers had an ascending bioaccumulation as fish age increased but with a little harmmattan shake-off during harmattan seasons with the range of $1.00-2.5 p p m$; then Mkpuma river fish liver had a continuous ascension of bioaccumulation ranging from 1.33.9ppm. The two controls, Ebonyi River and pond water fish livers witnessed cadmium bioaccumulation within the ranges of 0.3-1.6. (Fig.1). This could be attributed to natural influx of metals in the study area. 


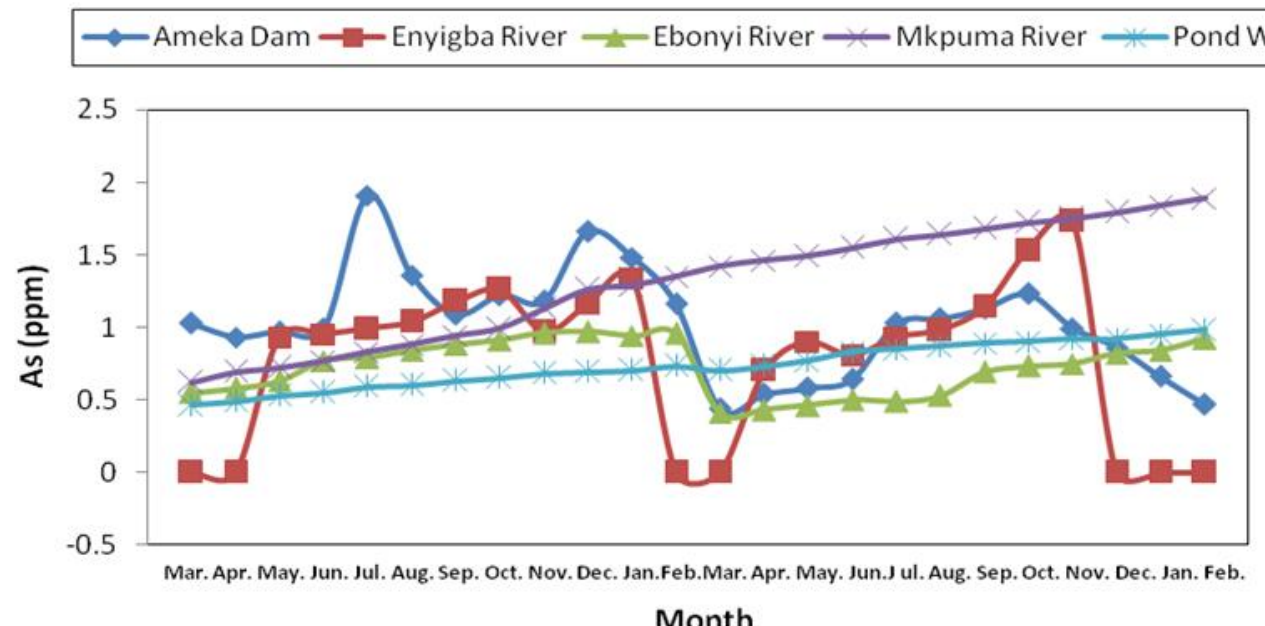

Figure 6. Variations of Arsenic (ppm) Content in the Liver of Catfish in Five Mining Sites in Ebonyi State from March 2011 to February 2013

Very high bioaccumulation of nickel was observed in fish liver of harvests from mine effluent areas with bioaccumulation ranging from 6.3-9.4. The 0.00 points as witnessed in January - March in Enyigba was as a result of small size fishes which had undeveloped livers at the time of harvest due to the effect of poachers. Akpara Dam and Mkpuma River showed an ascending bioaccumulation of nickel for the two years (i.e $6.5-9.4$ ppm).

Bioaccumulation of mercury increased as fish age increased. From the slope of the graph on mercury in Mkpuma River fish liver, its accumulation in Enyigba river and Akpara Dam liver fish ranging from $0.36-0.96$ and 0.42 0.70 . With fish age running from March February a drop from J anuary - April depicted a drop in fish size due to poaching by communal encroachment. Looking at the trend of bioaccumulation within the control fish liver, it recorded a $0.0-0.5$ range of bioaccumulation (Fig.3).

Chromium bioaccumulation varied in fish liver from month to month and increased as age of fish increased. It witnessed an even trend from April - January 2011 and dropped after poaching between January - March and continued along the trend in the five water bodies fish livers at the range of 13.11 26.17ppm (Fig.4).

Bioaccumulation of Lead ranged from the value of 5.0 - $14.5 \mathrm{ppm}$. Mkpuma fish liver showed highest lead bioaccumulation from 10.5 - 24.5ppm followed by Ameka Akpara Dam 10.8
- 9.6ppm with the two controls lying between the ranges of $5.0-9.6 \mathrm{ppm}$ (Fig.5).

Arsenic accumulation in the liver of fishes harvested from the five locations showed bioaccumulation from April to December before encroachment. This dropped as encroachment took place between January - March 2011 and took the same trend in 2012 with the exception of liver of fishes found in Mkpuma that did not witness any encroachment (Fig. 6). Encroachment reduced bioaccumulation as this could be because encroachment reduced the population of fishes which could reduce the possibility of selecting fishes that had heavy accumulation of heavy metals.

Since these livers are the active site of calcium uptake, deposition of skeletal elements is influenced by the degree of lead and cadmium effects on these cells. These two metals have been found to interfere with calcium uptake in fish embryos and early larval stages (Shephard and Simkiss 1978; Stouthart et al. 1994; Lashein 1999). The latter author stated that lead has more destructive effect on the chloride cells of Ctenopharyn godon idellus than cadmium. Rosenthal and Alderdice (1976) reviewed similar malformation observable after hatching and originating from tissue injury during early stages. Longwell et al. (1992) stated that some of these problems of development are probably the results of abnormal chromosome division of the fish embryo. Heath (1995) reported that exposure of embryos to lead at sublethal level can (but not necessarily always) induce a greater tolerance to that metal in the 
subsequent larvae. This situation was found for cadmium in rainbow trout (Beatie and Pascoe 1978) and may be attributed to metallothionein synthesis in adult fish which serves to sequester the metal (Heath 1995). A similar mechanism was recorded for mercury-induced Fundulus embryos (Weis 1984) and generally can be detected during the oxidative stress of other metals. The increased lead and cadmiummorphological and histological variations of Ctenopharyngodon idellus with developmental progress did not emphasize such metal tolerance. The beneficial health effects of fish are based on several studies from the last 25 years, most of which have linked fish consumption to several health benefits (Kmsella et al., 1990; Oomen et al., 2000; Kris-Etherton et al., 2002). However, one potential risk of dietary fish intake is its content of heavy metals. In humans, cadmium and lead have been associated with serious health effects on adults and children and one source of predisposition is the intake of fish with high content of either of these metals. Several authors like; Abernathy et al. (2003); Burger and Gochfeld (2005); Andreji et al (2006); Falco et al (2006) and Has-Schon et al (2006) have determined the levels of heavy metals bio-accumulation in different fish species and ascertained the levels of toxicity of consuming such fishes. Therefore the intake of fish should be regulated as the information regarding the species of fish consumed and its possible levels of content of heavy metals can be of benefit to diminish the hazard to public health (Domingo et al., 2007).

\section{Conclusion}

The result of the research showed that there were high level of bioaccumulation of Mercury, Lead, Arsenic, Cadmium, and Nickel which are hazardous and consuming such fishes could be detrimental to human health. The following recommendations have been made:

- There should be periodic monitoring of the rivers to avoid waste disposal which could lead to heavy metals accumulation.

- There should be further studies on the concentration of heavy metals in other fish tissues (brain, kidney, intestine, and heart) and species.
Abernathy, T.V. and Vineyard, R.N. (2003). Contribution of man-made activities to the pollution of the Kamennoe River basin. In: The natural waters in the area of Kostamus iron-ore deposite (NorthKarelia), Petrozavodsk, pp.13-15.

Andreji, M.S and Alien, P. (2006). Mercury accumulation profiles and their modification by interaction with cadmium and lead in the soft tissues of the Cichlid (Oreochromis aureus) during chronic exposure. Bull. Environ. Contain. Toxicol., 53:684-692.

Ademoroti, C.M.A. (1996). Standard methods for water and effluent analysis. Foludex press Ltd. Ibadan.P.182.

Beatie, J.H and Pascoe, D. (1978). Cadmium uptake by rainbow trout, Salmo gairderi, egg and alevins. Journal of Fish Biology 13: 631642.

Burger, A.D and Gochfeld, F.G (2005). Heavy metals in commercial fish in New Jersey. Journal of Environmental Research. 99:403412.

Domingo, E.R and, Amiard, J.C.; Amiard-Triquet, C.; Barka, S.; Pellerin, J.; Rainbow, P.S. (2007). Metallothioneins in aquatic invertebrates: Their role in metal detoxification and their use as biomarkers. Aquatic toxicology, 76(2), 160-202.

Ekpe, E.O. and Obiefuna, J.C. (2005). Effects of plant population and harvesting frequency on the agronomic characteristics and yield of waterleaf Talinum triangulare in the Southeastern Nigeria.

Ekpe, G., Llobet, J.M., Bocio, A., Domingo, J.L. (2006). Daily intake of arsenic, mercury, and lead by consumption of edible marine species. Journal of Agricultural Food Chemistry 54: 6106-6112.

Forstner, U., and Wittmann, G.T.W. (1981). Metal Pollution in the aquatic fishes, formed at different $\mathrm{pH}$ : aging effects on metal solubility and extractability by citrate. Journal of Environmental Toxicology and Chemistry. 20 (1): $122-126$.

\section{References}


Has-Schon, E., Bogut, I and Strelec, I (2006). Heavy metal profile in five fish species included in human diet, domiciled in the end flow of River Neretva (Croatia). Archeology and Environmental Contamination Toxicology 50: 545-551.

Health, A.G. (1995). Water Pollution and Fish Physiology. $2^{\text {nd }}$ edn. CRC Press, Boca Raton. U.S.A. P. 359.

Kris-Etherton P, Harris W.S, Appel L.J (2003). Fish Consumption, fish oil Omega-3 fatty acids, and cardiovascular disease. International J ournal of Aquatic Studies. 23:20-31.

Longwell, A.C., Change, A.S, Hebert, J. and Perry, D. (1992). Pollution and developmental abnormalities of Atlantic fishes. Envrionmental Biology Bulletin 35:1.

NPC (2006). National Population Commission. Abuja, Nigeria. A document on national population on Ebonyi State.

Oguzie, F. A. (2002). Heavy metals in the sediments of the Lower Ikpoba River, Benin
City. Nigeria. Sri Lanka Journal of Aquatic Sciences, 7: 35-44.

Oomen, C.M., Feskens, E.J., Rasanen, L., Fidanza, F., Nissinem, A.M., Menotti, A., Kok, F.J., Kromhout, D., (2000). Fish consumption and coronary heart disease mortality in Finland, Italy and the Netherlands. American Journal of Epidemiology. 151: 999-1006.

Stouthart, A.J.H., F.A.T. Spaning, R.A.C. Lock and S.E. Wendelaar-Bonga (1994). Effects of lowwater pH on lead toxicity to early life stages of the common carp, Cyprinus carpio. Aquatic Toxicology. 30: 137-151.

Tkacheva, V., Holopainen, I.J., Hyvarinen, H. (2000). Heavy metals in perch (Perca fluviatilis) from the Kostomuksha region (north-west Karelia, Russia). Boreal Environment Research 5, 209-220.

Weis, P.D. (1984). Metallothionein and mercury tolerance in the killifish, (fundulus heteroclitus). Marine Environmental Research. Vol. 3. Pp 153157. 